\title{
Isolation and characterization of multiple forms of rat liver UDP-glucuronate glucuronosyltransferase
}

\author{
Jayanta ROY CHOWDHURY, ${ }^{*} \ddagger$ Namita ROY CHOWDHURY,${ }^{*}$ Charles N. FALANY, $\dagger$ Thomas R. TEPHLY $\dagger$ \\ and Irwin M. ARIAS*\$ \\ ${ }^{*}$ Liver Research Center, Albert Einstein College of Medicine, Bronx, NY 10461, U.S.A., and †Toxicology Center, \\ Department of Pharmacology, University of Iowa, Iowa City, IA 52242, U.S.A.
}

\begin{abstract}
UDP-glucuronosyltransferase (EC 2.4.1.17) activity was solubilized from male Wistar rat liver microsomal fraction in Emulgen 911, and six fractions with the transferase activity were separated by chromatofocusing on PBE 94 ( $\mathrm{pH} 9.4$ to 6.0). Fraction I was further separated into Isoforms Ia, Ib and Ic by affinity chromatography on UDP-hexanolamine-Sepharose 4B. UDP-glucuronosyltransferase in Fraction III was further purified by rechromatofocusing (pH 8.7 to 7.5). UDP-glucuronosyltransferases in Fractions IV and $\mathrm{V}$ were purified by UDP-hexanolamine-Sepharose chromatography. The transferase isoforms in Fractions II, III, IV and V were finally purified by h.p.l.c. on a TSK G 3000 SW column. Purified UDPglucuronosyltransferase Isoforms Ia $\left(M_{\mathrm{r}} 51000\right)$, Ib $\left(M_{\mathrm{r}} 52000\right)$, Ic $\left(M_{\mathrm{r}} 56000\right)$, II $\left(M_{\mathrm{r}} 52000\right)$, IV $\left(M_{\mathrm{r}} 53000\right)$ and $\mathrm{V}\left(M_{\mathrm{r}} 53000\right)$ revealed single Coomassie Blue-stained bands on sodium dodecyl sulphate/polyacrylamidegel electrophoresis. Isoform III enzyme showed two bands of $M_{\mathrm{r}} 52000$ and 53000 . Comparison of the amino acid compositions by the method of Cornish-Bowden [(1980) Anal. Biochem. 105, 233-238] suggested that all UDP-glucuronosyltransferase isoforms are structurally related. Reverse-phase h.p.l.c. of tryptic peptides of individual isoforms revealed distinct 'maps', indicating differences in primary protein structure. The two bands of Isoform III revealed distinct electrophoretic peptide maps after limited enzymic proteolysis. After reconstitution with phosphatidylcholine liposomes, the purified isoforms exhibited distinct but overlapping substrate specificities. Isoform $\mathrm{V}$ was specific for bilirubin glucuronidation, which was not inhibited by other aglycone substrates. Each isoform, except Ia, was identified as a glycoprotein by periodic acid/Schiff staining.
\end{abstract}

\section{INTRODUCTION}

UDP-glucuronosyltransferase (EC 2.4.1.17) is concentrated in hepatic microsomal fraction (referred to below simply as 'microsomes'), and it catalyses the transfer of glucuronic acid from UDP-glucuronic acid to many metabolites and xenobiotics, forming $O-, N-, S$ - and $C$-glucuronides (Dutton, 1980; Dutton \& Burchell, 1977). In rat liver, UDP-glucuronosyltransferase activities for various aglycone substrates develop at different perinatal periods (Wishart, 1978a) and are differentially affected by various enzyme-inducing agents (Lucier \& McDaniel, 1977; Wishart, 1978b; Lillienblum et al., 1982), suggesting heterogeneity of the enzyme. Supportive evidence for multiplicity of UDP-glucuronosyltransferases came from chromatographic separation of two (Burchell, 1978; Bock et al., 1979; Weatherill \& Burchell, 1980; Roy Chowdhury et al., 1983) or three (Falany \& Tephly, 1983; Falany et al., 1983) forms of the enzyme with distinct substrate specificities from rat liver microsomes. However, antisera raised against one form of purified rat liver UDP-glucuronosyltransferase react with all forms of rat liver UDP-glucuronosyltransferases (Weatherill et al., 1980; Roy Chowdhury et al., 1983, 1985), and thus the structural multiplicity of rat liver UDP-glucuronosyltransferases has not been established. Identical proteins could possibly be chromatographically separated and exhibit functional difference because of different lipid or detergent content. Therefore, determination of the number of completely distinct forms requires structural analysis of purified isoforms.

In the present study, by combining chromatofocusing and affinity chromatography and using additional substrates, we have separated seven isoforms of UDP-glucuronosyltransferase from rat liver microsomes; five of these were purified after an additional affinitychromatographic or gel-permeation h.p.l.c. step. Analysis of peptides produced by enzymic proteolysis indicates that at least four isoforms differ in primary protein structure; differences in substrate specificities suggest the presence of three additional UDP-glucuronosyltransferase isoforms.

\section{EXPERIMENTAL}

\section{Materials}

Testosterone, oestrone, oestradiol-17 $\beta$, androsterone, bilirubin, 4-nitrophenol, 1-naphthol, aniline, 4-methylumbelliferone, UDP-glucuronic acid and egg phosphatidylcholine were obtained from Sigma Chemical Co. (St. Louis, MO, U.S.A.). Aniline was recrystallized from ethanol before use. ${ }^{3} \mathrm{H}$-labelled testosterone, oestrone, oestradiol-17 $\beta$, androsterone and 1-naphthol were obtained from New England Nuclear (Boston, MA, U.S.A.). $4-\mathrm{Nitro}\left[{ }^{14} \mathrm{C}\right]$ phenol was purchased from Cali-

\footnotetext{
Abbreviations used: $\mathrm{NaDodSO}_{4}$, sodium dodecyl sulphate.

¥ To whom correspondence should be addressed.

$\S$ Present address: Department of Physiology, Tufts University Medical School, Boston, MA 02111, U.S.A.
} 
fornia Bionuclear (Sun Valley, CA, U.S.A.) and was purified by diethyl ether extraction before use. Emulgen 911 was obtained from Kao-Atlas, Tokyo, Japan. Polybuffer Exchanger (PBE 94) and Polybuffer 96 were purchased from Pharmacia (Uppsala, Sweden). H.p.l.c. was performed on a Waters (Milford, MA, U.S.A.) chromatograph, with a $60 \mathrm{~cm}$ TSK G $3000 \mathrm{SW}$ gel-permeation chromatographic column. UDP-hexanolamine was synthesized and linked to Sepharose 4B as described by Sadler et al. (1979) and modified by Tukey \& Tephly (1981). Male Wistar rats (200-250 g) were purchased from Charles River Laboratories (Cambridge, MA, U.S.A.)

\section{Solubilization of rat liver microsomes}

Hepatic microsomes were prepared from male Wistar rats and solubilized in $0.5 \%$ Emulgen 911 as previously described (Falany et al., 1983). For most experiments, livers from two weight- and age-matched rats were pooled. To evaluate individual variation, single livers were used, with no difference in results.

\section{Chromatofocusing}

Chromatofocusing was performed with Polybuffer Exchanger 94 ( $20 \mathrm{ml}$ bed volume) as previously described (Falany et al., 1983), with the following modifications: glycerol and dithiothreitol were omitted from the equilibration and elution buffers, the $\mathrm{pH}$ range was extended (9.4 to 6.0), the protein load was decreased to $80 \mathrm{mg}(160 \mathrm{mg} / \mathrm{m}$ column length) of solubilized microsomal protein, and the elution rate was decreased to $0.2 \mathrm{ml} / \mathrm{min}$. UDP-glucuronosyltransferase activities for various substrates were determined as described below; six enzymically active chromatofocusing peaks were eluted (Fig. 1); the corresponding transferase isoforms were purified as follows.

Fraction I (elution pH 8.9). Fractions were applied at $0.6 \mathrm{ml} / \mathrm{h}$ to a $15 \mathrm{ml}$ UDP-hexanolamine-Sepharose 4B column that had been equilibrated with 25 mM-ethanolamine/acetate buffer, $\mathrm{pH} 8.0$, containing $5 \mathrm{~mm}-\mathrm{MgCl}_{2}$ and $0.5 \mathrm{mg}$ of Emulgen $911 / \mathrm{ml}$. UDP-glucuronosyltransferases were eluted sequentially with 2 bed volumes each of $30 \mathrm{~mm}-\mathrm{KCl}$ (Fraction Ia), $50 \mu \mathrm{M}-\mathrm{UDP}$-glucuronic acid (Fraction Ib) and $5 \mathrm{~mm}$-UDP-glucuronic acid (Fraction Ic) in equilibration buffer. Eluate was collected in $2.5 \mathrm{ml}$ fractions. Enzymically active fractions were pooled and concentrated by negative pressure dialysis against

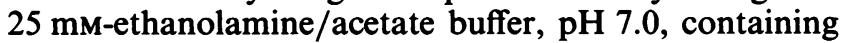
$0.5 \mathrm{mg}$ of Emulgen $911 / \mathrm{ml}$ in a Micro-Prodicon concentrator (Bio-Molecular Dynamics, Beaverton, OR, U.S.A.).

Fraction II (elution pH 8.4). Pooled fractions were concentrated to $0.25 \mathrm{ml}$, and UDP-glucuronosyltransferase was purified by h.p.l.c. as follows. A TSK G 3000 SW column was equilibrated with $25 \mathrm{~mm}$-potassium phosphate buffer, $\mathrm{pH} 7.0$, containing $30 \mathrm{~mm}-\mathrm{KCl}$ and $0.5 \mathrm{mg}$ of Emulgen $911 / \mathrm{ml}$. The procedure was performed at room temperature; the column was cooled by keeping the elution buffer on ice. Concentrated Fraction II, containing approx. $0.1-0.5 \mathrm{mg}$ of protein, was applied to the column, and proteins were eluted at $0.5 \mathrm{ml} / \mathrm{min}$ with the equilibration buffer. The eluate was collected on ice in $0.5 \mathrm{ml}$ fractions. Enzymically active fractions were pooled and concentrated by negative pressure dialysis.
Fraction III (elution pH 8.0). Since Fraction III yielded two protein bands on $\mathrm{NaDodSO}_{4} /$ polyacrylamide-gel electrophoresis (see the Results section), we attempted to separate these bands by rechromatofocusing. The pooled fractions were adjusted to $\mathrm{pH} 8.7$ by addition of 25 mM-ethanolamine containing $0.05 \%$ Emulgen 911 ; chromatofocusing was performed as described in a $\mathrm{pH}$ range from 8.7 to 7.5 . Fractions with transferase activity for testosterone were purified by h.p.l.c.

Fraction IV (elution pH 7.8) and Fraction V (elution pH 7.5). UDP-glucuronosyltransferase from these fractions were purified by UDP-hexanolamine-Sepharose 4B chromatography as described above, except that equilibration and wash buffers did not contain $\mathrm{KCl}$ and the transferases were eluted with $1 \mathrm{~mm}$-UDP-glucuronic acid. UDP-glucuronosyltransferase isoforms were purified from enzymically active fractions by h.p.l.c. as described above.

Fraction VI (elution pH 6.5). This fraction had activity for oestrone and oestradiol-17 $\beta$, contained many bands on $\mathrm{NaDodSO}_{4} /$ polyacrylamide-gel electrophoresis and was not further purified.

\section{Enzyme assays}

UDP-glucuronosyltransferase activities were reconstituted as follows. Phosphatidylcholine liposomes were prepared as described by Burchell (1980). For enzyme assay in all chromatographic fractions (but not for solubilized microsomes), phosphatidylcholine liposomes were added to the incubation mixture $(1 \mathrm{mg} / \mathrm{ml}$ for bilirubin and $0.1 \mathrm{mg} / \mathrm{ml}$ for other substrates). Since all samples contained Emulgen 911, no additional detergent was added.

UDP-glucuronosyltransferase activities towards bilirubin (Jansen et al., 1977) and aniline (Axelrod et al., 1958) were assayed colorimetrically; the activity towards 4-methylumbelliferone was determined fluorimetrically (Arias, 1961). The transferase activities towards 4nitrophenol, 1-naphthol, oestrone, testosterone, oestradiol-17 $\beta$ and androsterone were quantified by radioassay (Dutton et al., 1981). Glucuronidation of bilirubin was assayed at $\mathrm{pH} 7.8$, of 4-nitrophenol at $\mathrm{pH} 7.4$, and of all other substrates at $\mathrm{pH}$ 8.0. For all assays, product formation was linear with enzyme concentrations and incubation time.

Protein was determined by the method of Bradford (1976), with bovine serum albumin as standard. To correct for interference by co-eluted components of the chromatofocusing buffer, an identical chromatofocusing was performed in the absence of protein, and each fraction was used as a blank for the corresponding fraction in which solubilized microsomes were chromatofocused.

\section{$\mathrm{NaDodSO}_{4} /$ polyacrylamide-gel electrophoresis}

$\mathrm{NaDodSO}_{4} /$ polyacrylamide gel electrophoresis of the chromatofocusing fractions and purified transferase isoforms were performed with and without treatment with 2-mercaptoethanol (Laemmli, 1970); protein bands were identified by Coomassie Blue staining. The gels were also stained with periodic acid/Schiff stain to identify glycoproteins (Gordon, 1969). 

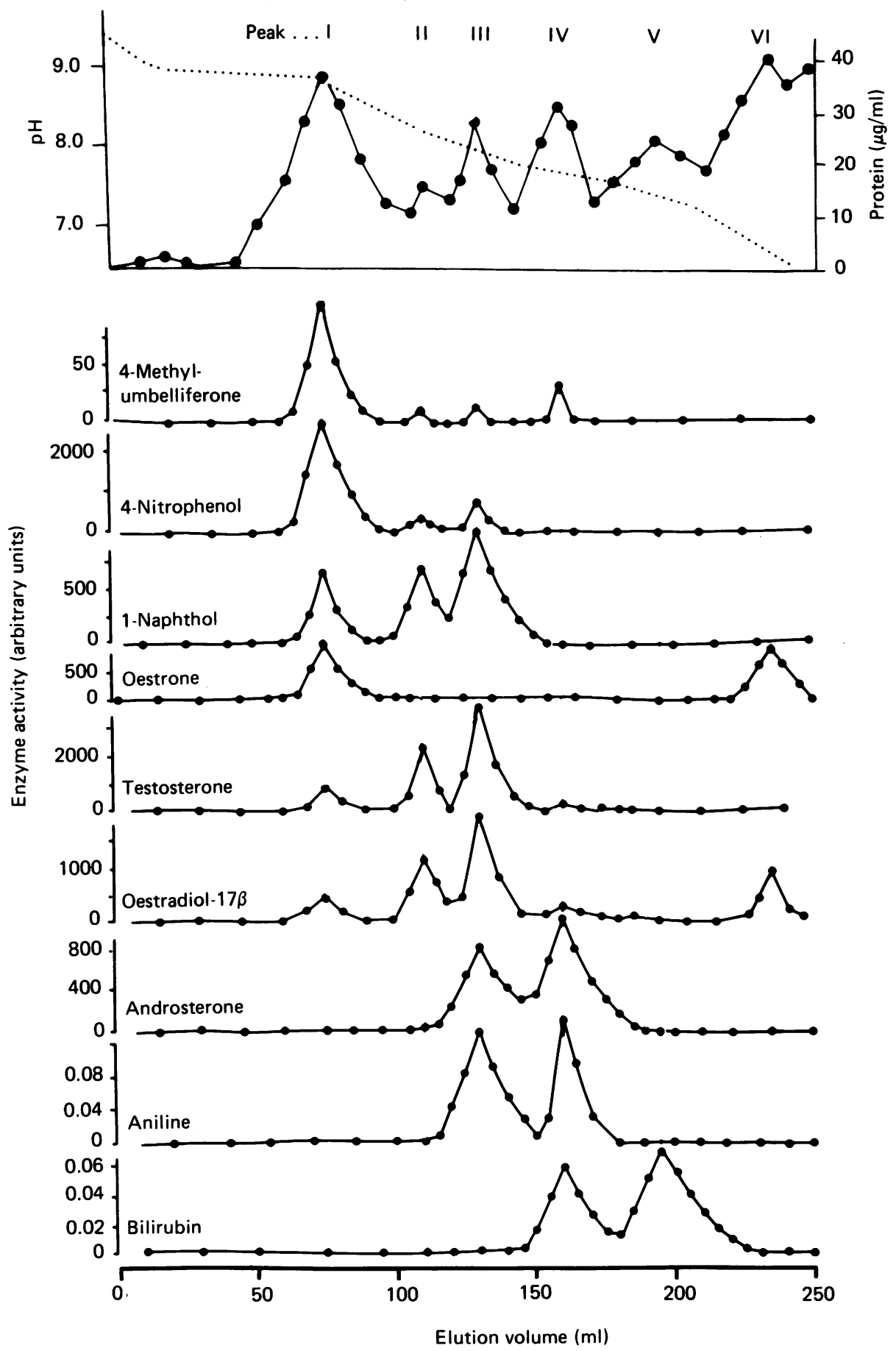

Fig. 1. Chromatofocusing of solubilized rat liver microsomes

Microsomes were solubilized in Emulgen 911, and UDP-glucuronosyltransferase activities were separated by chromatofocusing (range from pH 9.4 to $6.0 ; \cdots \cdots$ ) as described in the Experimental section. Enzyme activities (arbitrary units) were assayed after reconstitution with phosphatidylcholine liposomes. Data are from a single representative experiment.

\section{Gel-permeation chromatography}

To determine the apparent molecular size of nondenatured transferase Isoforms I and III $(100 \mu \mathrm{g}$ in $150 \mu \mathrm{l})$, gel-permeation chromatography was performed on a Bio-Gel A-1.5m column (internal diam. $1 \mathrm{~cm}$, bed volume $40 \mathrm{ml}$, equilibrated with $25 \mathrm{~mm}$-ethanolamine/ acetate buffer, $\mathrm{pH} 8.0$, containing $0.05 \%$ Emulgen 911). The transferases were eluted with the equilibration buffer and enzyme activities towards 4-nitrophenol and testosterone were assayed. Albumin, rat IgG and catalase were used as $M_{\mathrm{r}}$ markers.

\section{H.p.l.c. mapping of tryptic peptides}

The purified UDP-glucuronosyltransferase isoforms were reduced with dithiothreitol, alkylated with iodoacetamide and digested to completion by two $90 \mathrm{~min}$ 


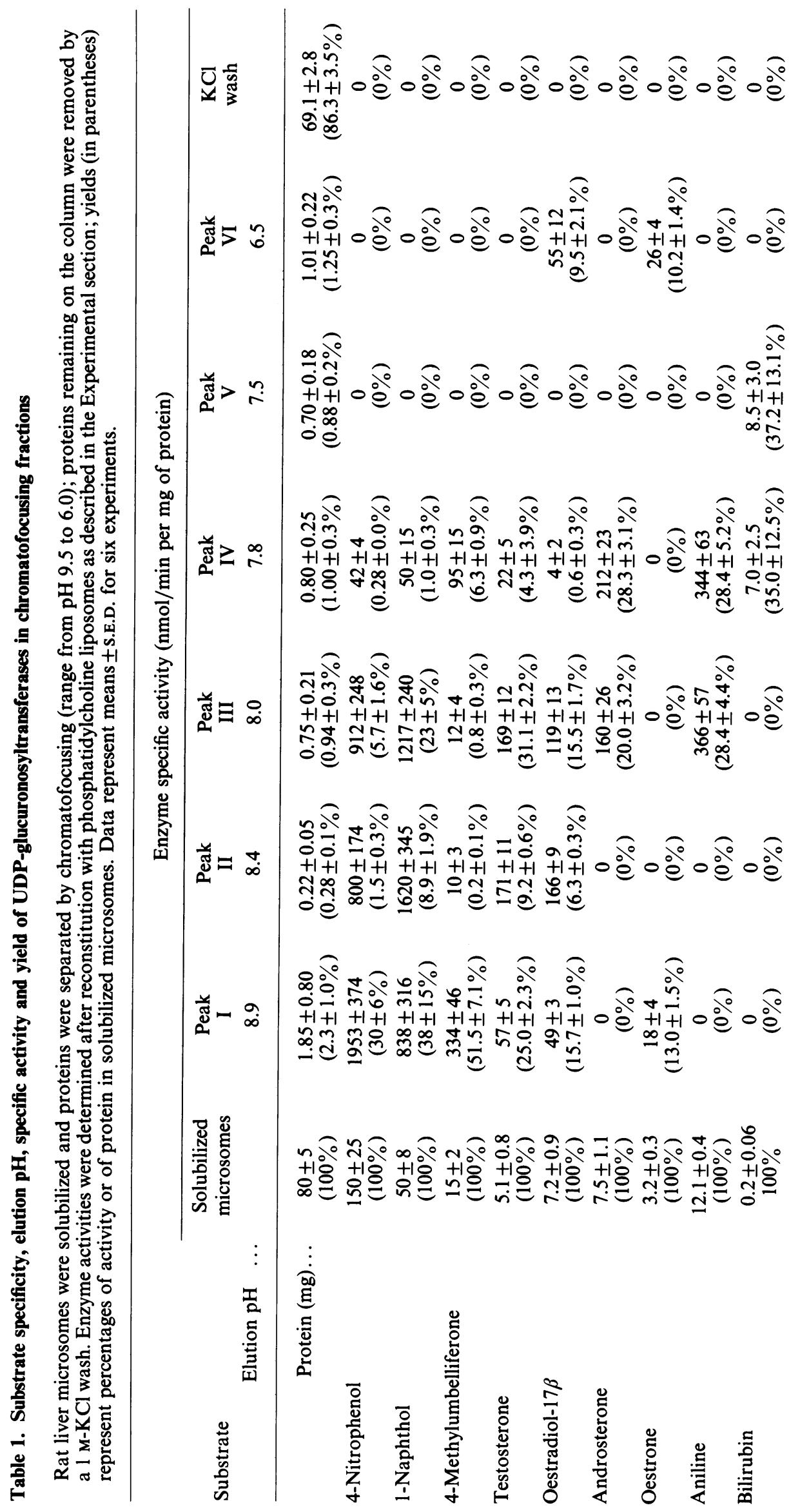


incubations with trypsin [1-chloro-4-phenyl-3-L-tosylamidobutan-2-one ('TPCK')-treated] as described by Spiess et al. (1981); a third 90 min incubation did not result in any change in the peptide maps. The peptides were freeze-dried, dissolved in $0.1 \%(\mathrm{v} / \mathrm{v})$ trifluoroacetic acid, freeze-dried again, redissolved in $0.2 \mathrm{ml}$ of $0.1 \%$ trifluoroacetic acid and resolved by reverse-phase h.p.l.c. on Waters $\mathrm{C}-18$ columns $(10 \mu \mathrm{m}$ particle size; $4.6 \mathrm{~mm} \times 300 \mathrm{~mm}$ ) by a minor modification of the method of Mahoney \& Hermodson (1980), as follows. The column was equilibrated with $0.1 \%$ trifluoroacetic acid, and the peptides ( $150 \mu l$ of solution) were eluted at $1 \mathrm{ml} / \mathrm{min}$ with $0.1 \%$ trifluoracetic acid for $10 \mathrm{~min}$, followed by a $0-75 \%$ linear gradient $(1.11 \% / \mathrm{min})$ of acetonitrile $(80 \%, \mathrm{v} / \mathrm{v})$ in $0.1 \%$ trifluoroacetic acid; detection was at $214 \mathrm{~nm}$. When incubation was performed with trypsin alone in the absence of any UDPglucuronosyltransferase isoform, no major peptide peak was observed.

Limited enzymic proteolysis of the two $\mathrm{NaDodSO}_{4} /$ polyacrylamide-gel-electrophoretic bands of Isoform III

Isoform III yielded two protein bands on $\mathrm{NaDodSO}_{4} /$ $10 \%$-polyacrylamide-gel electrophoresis (see the Results section); these bands could not be separated by rechromatofocusing, affinity chromatography and h.p.l.c. To compare their structure, portions of the gel that contained the Coomassie Blue stain bands were separately removed with a blade. When the gel slices were placed on the top of $\mathrm{NaDodSO}_{4} /$ polyacrylamide slab gels and re-electrophoresed, the two bands migrated separately as single bands without contamination with each other. The proteins were labelled with ${ }^{125}$ I by the chloramine- $T$ method, and digested within the gel slices with staphylococcal proteinase V8 (30 min to $4 \mathrm{~h}$ )(Elder et al., 1977). The gel slices were placed on the top of a $10-26 \%$-acrylamide gradient $\mathrm{NaDodSO}_{4} /$ polyacrylamide slab gel, and proteins were electrophoresed for $16 \mathrm{~h}$ at $75 \mathrm{~V}$ at $11^{\circ} \mathrm{C}$; the peptides were detected by autoradiography (Elder et al., 1977).

\section{Amino acid analysis}

Amino acid analysis of the UDP-glucuronosyltransferase isoforms from three purification batches was performed in duplicate by the performic acid oxidation method, with a Beckman amino acid analyser (Glazer et al., 1969). Acid hydrolysis for 8, 16 or $24 \mathrm{~h}$ yielded similar results; therefore $16 \mathrm{~h}$ hydrolysis was routinely used. The amino acid compositions were compared in accordance with the procedure of Cornish-Bowden (1980).

\section{RESULTS}

\section{Separation and purification of UDP-glucuronosyltrans-} ferase isoforms

Enzyme activities, $\mathrm{pH}$ and elution volume of chromatofocusing fractions are shown in Fig. 1. UDPglucuronosyltransferase specific activities and enzyme and protein recovery in chromatofocusing fractions are shown in Table 1; Fig. 2 shows $\mathrm{NaDodSO}_{4} /$ polyacrylamide-gel-electrophoretic analysis of the enzymically active fractions. The surprisingly high degree of separation and purification of UDP-glucuronosyltransferase isoforms (Figs. 1 and 2) and the relative symmetry of the protein peaks were dependent on the detergent used to solubilize the microsomes. When Lubrol-WX or Triton

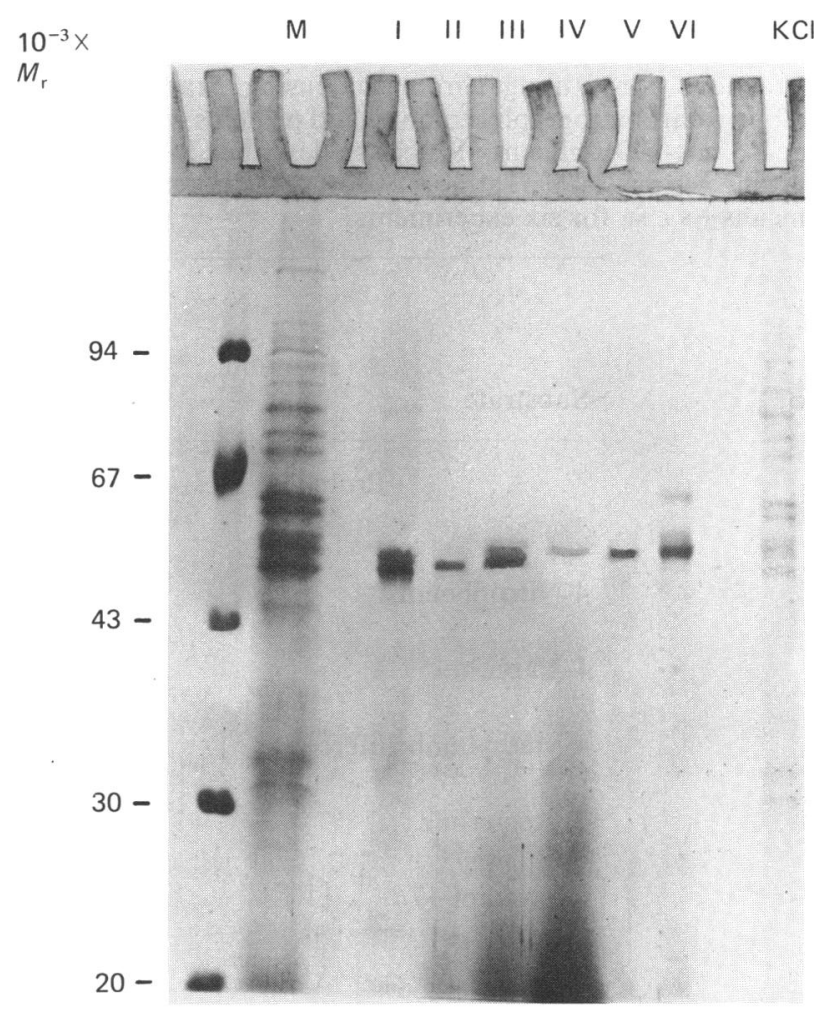

Fig. 2. $\mathrm{NaDodSO}_{4}$ /polyacrylamide-gel electrophoresis of chromatofocusing fractions

Chromatofocusing of solubilized microsomal proteins was performed as in Fig. 1; after the $\mathrm{pH}$ of the eluate had reached 6.0 , residual proteins were eluted with $1 \mathrm{M}-\mathrm{KCl}$ containing $0.05 \%$ Emulgen 911 . Solubilized microsomal proteins (M), fractions constituting chromatofocusing Peaks (I, II, III, IV, V and VI) and the $\mathrm{KCl}$ eluate were electrophoresed on $\mathrm{NaDodSO}_{4} / 10 \%$-polyacrylamide gel slabs; electrophoresis was continued for $60 \mathrm{~min}$ after the dye front reached the bottom of the gel. $M_{\mathbf{r}}$ markers are shown on the left. Components of the chromatofocusing buffer migrated to the lower end of the gel.

$\mathrm{X}-100$ was used, peaks of enzyme activity showed greater overlap. UDP-hexanolamine-Sepharose chromatography was required for separation of UDP-glucuronosyltransferase isoforms contained in chromatofocusing Fraction I (elution $\mathrm{pH} 8.9)$ into Isoforms Ia (30 mM-KCl eluate), Ib (50 $\mu \mathrm{M}$-UDP-glucuronic acid eluate) and Ic ( 5 mM-UDP-glucuronic acid eluate); enzyme specific activities and recovery are shown in Table 2. Fraction III showed two bands on $\mathrm{NaDodSO}_{4} /$ polyacrylamide-gel electrophoresis; these bands could not be separated by rechromatofocusing on a shallower gradient. UDPglucuronosyltransferases in Fractions IV and V were partially purified by UDP-hexanolamine-Sepharose chromatography. On gel-permeation h.p.l.c. of Fractions II, III, IV and V, the transferase activities were eluted immediately after the void volume; this procedure removed the chromatofocusing buffer and traces of contaminating proteins. Enzyme specific activities and recovery of the purified transferase Isoforms II-V are shown in Table 3. Each isoform, except Isoform V, had distinct but partially overlapping substrate-specificity; Isoform $\mathrm{V}$ had activity towards bilirubin alone, which was not inhibited by the other aglycones. 
Table 2. Specific activity and yield of UDP-hexanolamine-Sepharose 4B affinity chromatography of chromatofocusing Fraction I

Fractions constituting chromatofocusing Fraction I (see Table 1) were applied to a UDP-hexanolamine-Sepharose 4B affinity-chromatography column, and proteins were sequentially eluted with $30 \mathrm{mM}-\mathrm{KCl}, 50 \mu \mathrm{M}$-UDP-glucuronic acid (UDPGA) and $5 \mathrm{~mm}$-UDP-glucuronic acid as described in the Experimental section. Specific UDP-glucuronosyltransferase activities are given; yields (in parentheses) represent percentages of activity or of protein in solubilized microsomes. Data represent means \pm S.E.M. for six experiments.

\begin{tabular}{|c|c|c|c|}
\hline \multirow[b]{2}{*}{ Substrate } & \multicolumn{3}{|c|}{ Enzyme specific activity (nmol/min per $\mathrm{mg}$ of protein) } \\
\hline & $\underset{\mathrm{Ia}}{\mathrm{KCl}(30 \mathrm{mM})}$ & $\stackrel{\text { Ib }}{\text { UDPGA }(50 \mu \mathrm{M})}$ & $\begin{array}{l}\text { Ic } \\
\text { UDPGA }(5 \mathrm{~mm})\end{array}$ \\
\hline Protein $(\mu \mathrm{g}) \ldots$ & $\begin{array}{c}970 \pm 140 \\
(1.21 \pm 0.2 \%)\end{array}$ & $\begin{array}{c}380 \pm 23 \\
(0.48 \pm 0.3 \%)\end{array}$ & $\begin{array}{c}240 \pm 16 \\
(0.30 \pm 0.02 \%)\end{array}$ \\
\hline 4-Nitrophenol & $\begin{array}{l}816 \pm 118 \\
(6.6 \pm 1.2 \%)\end{array}$ & $\begin{array}{l}2621 \pm 223 \\
(8.3 \pm 2.7 \%)\end{array}$ & $\begin{array}{l}4830 \pm 320 \\
(9.5 \pm 3.5 \%)\end{array}$ \\
\hline 1-Naphthol & $\begin{array}{l}150 \pm 50 \\
(3.6 \pm 1.2 \%)\end{array}$ & $\begin{array}{l}1520 \pm 288 \\
(14.4 \pm 2.7 \%)\end{array}$ & $\begin{array}{l}2310 \pm 380 \\
(13.9 \pm 2.3 \%)\end{array}$ \\
\hline 4-Methylumbelliferone & $\begin{array}{l}0 \\
(0 \%)\end{array}$ & $\begin{array}{l}0 \\
(0 \%)\end{array}$ & $\begin{array}{l}1190 \pm 220 \\
(23.8 \pm 4.4 \%)\end{array}$ \\
\hline Testosterone & $\begin{array}{l}23.1 \pm 5.1 \\
(5.5 \pm 1.2 \%)\end{array}$ & $\begin{array}{c}165 \pm 68 \\
(15.4 \pm 6.3 \%)\end{array}$ & $\begin{array}{c}0 \\
(0 \%)\end{array}$ \\
\hline Oestradiol-17 $\beta$ & $\begin{array}{l}17.0 \pm 4.0 \\
(2.9 \pm 6.6 \%)\end{array}$ & $\begin{array}{l}150 \pm 47 \\
(9.9 \pm 3.1 \%)\end{array}$ & $\begin{array}{l}0 \\
(0 \%)\end{array}$ \\
\hline Oestrone & 0 & 0 & 0 \\
\hline
\end{tabular}

Table 3. H.p.l.c. of chromatofocusing fractions with UDP-glucuronosyltransferase activity

Chromatofocusing Fractions II, IV and V (Fig. 1) were separately pooled and concentrated. Fraction III was rechromatofocused; enzymically active fractions were pooled and concentrated. UDP-glucuronosyltransferase activities were purified by gelpermeation h.p.l.c. as described in the Experimental section. Specific enzyme activities are given; yields (in parentheses) represent percentages of activity or of protein in solubilized microsomes. Data are means \pm S.E.M. for six experiments.

Enzyme specific activity ( $\mathrm{nmol} / \mathrm{min}$ per $\mathrm{mg}$ of protein)

\begin{tabular}{|c|c|c|c|c|}
\hline \multirow{2}{*}{$\begin{array}{l}\text { Chromatofocusing fraction } \\
\text { Substrate }\end{array}$} & \\
\hline & II & III & IV & $\mathbf{V}$ \\
\hline Protein $(\mu \mathrm{g}) \ldots$ & $\begin{array}{c}96 \pm 27 \\
(0.12 \pm 0.03 \%)\end{array}$ & $\begin{array}{c}317 \pm 106 \\
(0.40 \pm 0.13 \%)\end{array}$ & $\begin{array}{c}196 \pm 78 \\
(0.25 \pm 0.10 \%)\end{array}$ & $\begin{array}{c}181 \pm 53 \\
(0.23 \pm 0.07 \%)\end{array}$ \\
\hline 4-Nitrophenol & $\begin{array}{l}1500 \pm 366 \\
(1.25 \pm 0.29 \%)\end{array}$ & $\begin{array}{l}1510 \pm 440 \\
(4.0 \pm 1.2 \%)\end{array}$ & $\begin{array}{c}60 \pm 6 \\
(0.10 \pm 0.01 \%)\end{array}$ & $\begin{array}{c}0 \\
(0 \%)\end{array}$ \\
\hline 1-Naphthol & $\begin{array}{l}1659 \pm 510 \\
(4.0 \pm 1.2 \%)\end{array}$ & $\begin{array}{l}2015 \pm 268 \\
(16.0 \pm 2.2 \%)\end{array}$ & $\begin{array}{c}71 \pm 21 \\
(0.3 \pm 0.1 \%)\end{array}$ & $\begin{array}{c}0 \\
(0 \%)\end{array}$ \\
\hline 4-Methylumbelliferone & $\begin{array}{c}20 \pm 3 \\
(0.16 \pm 0.02 \%)\end{array}$ & $\begin{array}{c}21 \pm 6 \\
(0.60 \pm 0.16 \%)\end{array}$ & $\begin{array}{l}135 \pm 22 \\
(2.2 \pm 0.4 \%)\end{array}$ & $\begin{array}{l}0 \\
(0 \%)\end{array}$ \\
\hline Testosterone & $\begin{array}{c}320 \pm 22 \\
(7.53 \pm 0.5 \%)\end{array}$ & $\begin{array}{c}280 \pm 20 \\
(21.8 \pm 1.6 \%)\end{array}$ & $\begin{array}{c}30 \pm 8 \\
(1.4 \pm 0.4 \%)\end{array}$ & $\begin{array}{c}0 \\
(0 \%)\end{array}$ \\
\hline Oestradiol-17 $\beta$ & $\begin{array}{l}310 \pm 22 \\
(5.1 \pm 0.4 \%)\end{array}$ & $\begin{array}{c}198 \pm 21 \\
(10.9 \pm 1.2 \%)\end{array}$ & $\begin{array}{l}0 \\
(0 \%)\end{array}$ & $\begin{array}{l}0 \\
(0 \%)\end{array}$ \\
\hline Androsterone & $\begin{array}{c}0 \\
(0 \%)\end{array}$ & $\begin{array}{c}70 \pm 13 \\
(3.7 \pm 0.7 \%)\end{array}$ & $\begin{array}{l}298 \pm 18 \\
(9.7 \pm 0.6 \%)\end{array}$ & $\begin{array}{c}0 \\
(0 \%)\end{array}$ \\
\hline Aniline & $\begin{array}{l}0 \\
(0 \%)\end{array}$ & $\begin{array}{c}605 \pm 92 \\
(19.8 \pm 3.0 \%)\end{array}$ & $\begin{array}{l}485 \pm 90 \\
(9.8 \pm 1.8 \%)\end{array}$ & $\begin{array}{l}0 \\
(0 \%)\end{array}$ \\
\hline Bilirubin & $\begin{array}{c}0 \\
(0 \%)\end{array}$ & $\begin{array}{c}0 \\
(0 \%)\end{array}$ & $\begin{array}{c}20 \pm 8 \\
(24.5 \pm 9.8 \%)\end{array}$ & $\begin{array}{c}23 \pm 6 \\
(26.0 \pm 6.7 \%)\end{array}$ \\
\hline
\end{tabular}

$\mathrm{NaDodSO}_{4} /$ polyacrylamide-gel electrophoresis of purified isoforms

$\mathrm{NaDodSO}_{4} /$ polyacrylamide-gel electrophoresis revealed single Coomassie Blue-stained bands for each purified isoform (Isoform Ia, $M_{\mathrm{r}} 51000$; Ib and II, $M_{\mathrm{r}}$ 52000; Isoform Ic, $M_{\mathrm{r}}$ 56000; IV and V, $M_{\mathrm{r}}$ 53000), except for Isoform III, which showed two bands $\left(M_{\mathrm{r}}\right.$ 52000 and 53000) (Fig. 3a). Some variation in the electrophoretic mobility of the isoforms was observed 


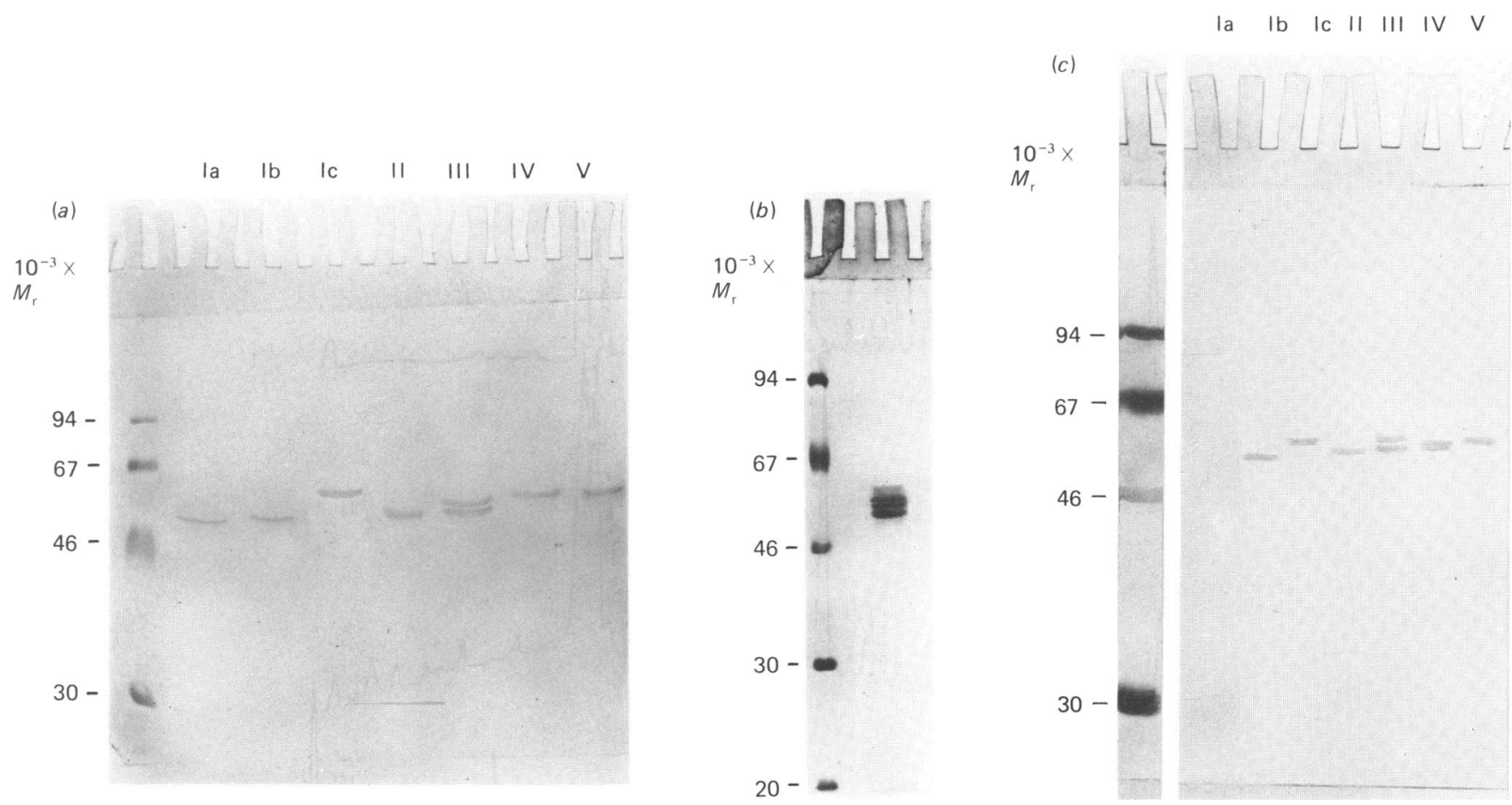

Fig. 3. $\mathrm{NaDodSO}_{4} /$ polyacrylamide-gel electrophoresis of purified UDP-glucuronosyltransferase isoforms

UDP-glucuronosyltransferase isoforms were purified by a combination of chromatofocusing, affinity chromatography and gel permeation h.p.l.c. as described in Fig. 1 and in the Experimental section. Electrophoresis was performed on $\mathrm{NaDodSO}_{4} / 10 \%-$ polyacrylamide gel slabs as in Fig. 2. (a) Coomassie Blue-stained gel; (b) electrophoretic resolution of a mixture of all purified isoforms; (c) periodic acid/Schiff-stained electrophoretogram of Isoforms I to V. Migration of $M_{\mathrm{r}}$ markers is shown on the left of each panel.

Table 4. Amino acid compositions of UDP-glucuronosyltransferase isoforms

Amino acid analysis of purified UDP-glucuronosyltransferase isoforms was performed by the performic acid oxidation method as described in the Experimental section. Results are given as means \pm S.E.M. for three experiments.

\begin{tabular}{|c|c|c|c|c|c|c|}
\hline \multirow[b]{2}{*}{ Amino acid } & \multirow[b]{2}{*}{ Isoform } & \multicolumn{5}{|c|}{ Composition (residues/100 residues) } \\
\hline & & $\ldots$ & II & III & IV & $\mathbf{V}$ \\
\hline Asp & & $8.5 \pm 0.7$ & $8.7 \pm 0.8$ & $8.8 \pm 0.9$ & $10.1 \pm 0.8$ & $11.5 \pm 1.0$ \\
\hline Thr & & $5.4 \pm 0.5$ & $5.0 \pm 0.4$ & $5.3 \pm 0.5$ & $5.6 \pm 0.4$ & $6.3 \pm 0.4$ \\
\hline Ser & & $4.8 \pm 0.5$ & $5.1 \pm 0.04$ & $6.3 \pm 0.4$ & $4.6 \pm 0.4$ & $6.3 \pm 0.5$ \\
\hline Glu & & $7.4 \pm 0.6$ & $9.2 \pm 0.8$ & $10.0 \pm 0.8$ & $8.0 \pm 0.8$ & $9.3 \pm 0.8$ \\
\hline Pro & & $6.4 \pm 0.5$ & $6.1 \pm 0.5$ & $4.7 \pm 0.5$ & $7.0 \pm 0.7$ & $6.0 \pm 0.5$ \\
\hline Gly & & $9.2 \pm 0.8$ & $8.7 \pm 0.7$ & $10.4 \pm 0.9$ & $8.8 \pm 0.9$ & $9.0 \pm 0.7$ \\
\hline Ala & & $6.4 \pm 0.4$ & $5.9 \pm 0.5$ & $8.2 \pm 0.7$ & $7.0 \pm 0.7$ & $6.0 \pm 0.5$ \\
\hline Val & & $6.4 \pm 0.5$ & $6.6 \pm 0.5$ & $6.2 \pm 0.6$ & $6.6 \pm 0.6$ & $5.4 \pm 0.5$ \\
\hline Met & & $2.5 \pm 0.4$ & $2.5 \pm 0.1$ & $2.2 \pm 0.2$ & $3.0 \pm 0.2$ & $2.4 \pm 0.2$ \\
\hline Ile & & $5.4 \pm 0.4$ & $5.9 \pm 0.5$ & $5.2 \pm 0.5$ & $8.3 \pm 0.7$ & $4.1 \pm 0.5$ \\
\hline Leu & & $11.1 \pm 0.9$ & $10.3 \pm 1.1$ & $9.5 \pm 1.0$ & $9.3 \pm 0.8$ & $10.5 \pm 0.9$ \\
\hline Tyr & & $3.1 \pm 0.3$ & $1.0 \pm 0.2$ & $1.1 \pm 0.3$ & $2.0 \pm 0.2$ & $3.0 \pm 0.3$ \\
\hline Phe & & $6.0 \pm 0.6$ & $6.7 \pm 0.6$ & $4.5 \pm 0.3$ & $5.2 \pm 0.4$ & $5.4 \pm 0.6$ \\
\hline $\mathrm{His}$ & & $3.4 \pm 0.3$ & $3.4 \pm 0.3$ & $3.1 \pm 0.3$ & $3.2 \pm 0.3$ & $2.8 \pm 0.3$ \\
\hline Lys & & $7.7 \pm 0.6$ & $8.8 \pm 1.0$ & $8.8 \pm 0.8$ & $6.8 \pm 0.6$ & $6.4 \pm 0.7$ \\
\hline Arg & & $4.2 \pm 0.5$ & $3.6 \pm 0.3$ & $4.4 \pm 0.3$ & $2.8 \pm 0.3$ & $3.6 \pm 0.5$ \\
\hline Cys & & $2.0 \pm 0.3$ & $1.9 \pm 0.2$ & $1.0 \pm 0.2$ & $2.0 \pm 0.2$ & $2.1 \pm 0.3$ \\
\hline
\end{tabular}

from experiment to experiment, and therefore the stated $M_{\mathrm{r}}$ values should be considered approximate. When the purified transferase Isoforms Ia, Ib, Ic, II, III, IV and V were mixed and analysed by $\mathrm{NaDodSO}_{4} /$ polyacrylamide- gel electrophoresis, four protein bands in the $M_{\mathrm{r}}$ range approx. 51000-56000 were separated (Fig. 3b). Proteins from Fraction VI showed several Coomassie Blue-stained bands; it was not possible to determine which band 


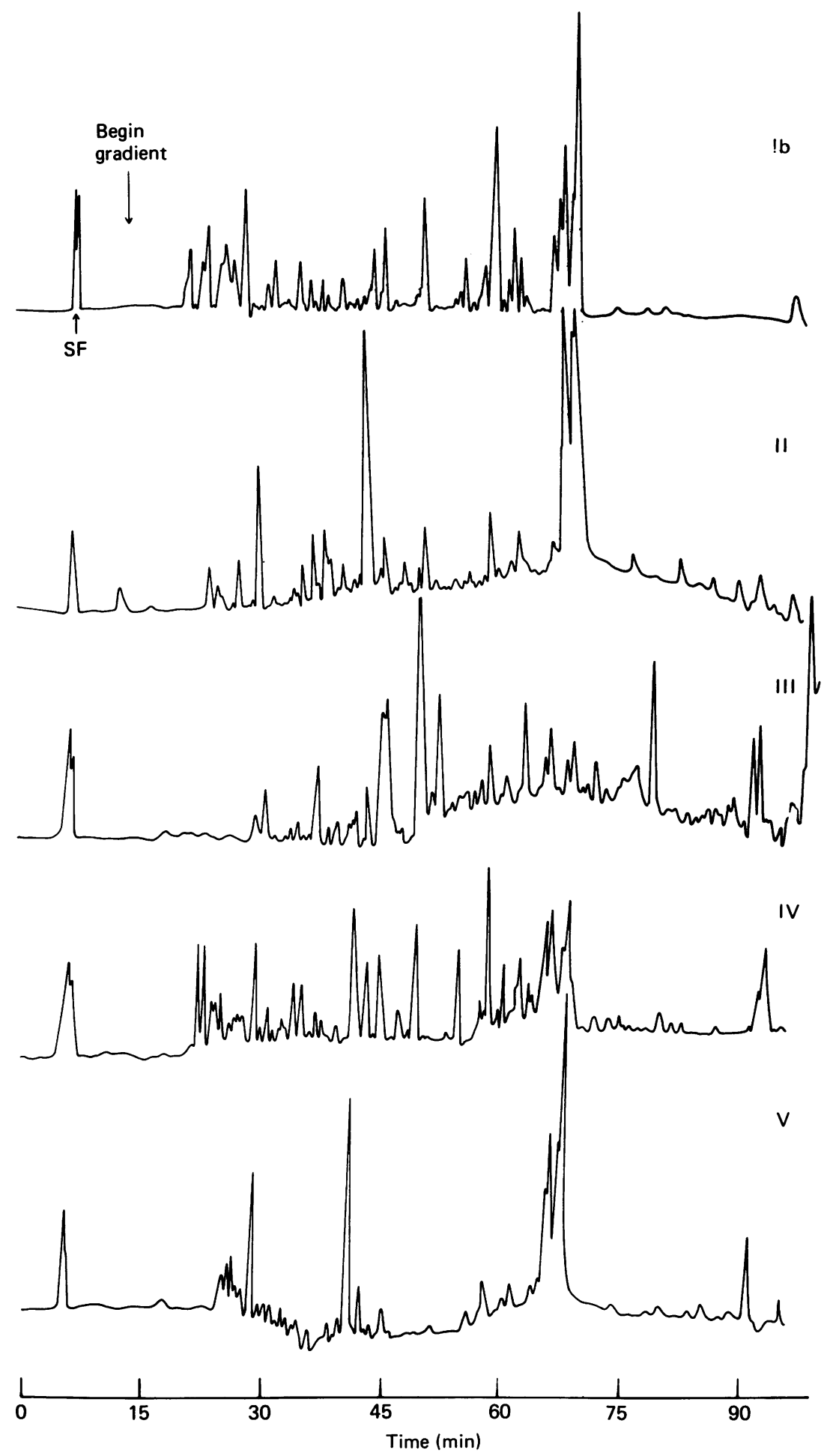

Fig. 4. H.p.l.c. tryptic peptide maps of UDP glucuronosyltransferase isoforms

The purified isoforms (Ib, II, III, IV and V) were reduced, alkylated, digested with trypsin and dissolved in $0.1 \%$ trifluoroacetic acid and resolved on a Waters $\mu$ Bondapak C-18 column with an acetonitrile gradient in $0.1 \%$ trifluoracetic acid as described in the Experimental section. Detection was at $214 \mathrm{~nm}$; the absorbance at full scale was 0.5 unit. Abbreviation: SF, solvent front.

represented UDP-glucuronosyltransferase. Isoforms Ib, II, III, IV and V were periodic acid/Schiff-positive; isoform Ia was periodic acid/Schiff-negative (Fig. $3 c$ ). Isoform Ic enzyme was obtained in small amounts, and its periodic acid/Schiff reaction was uncertain.
Amino acid compositions of the UDP-glucuronosyltransferase isoforms

The amino acid compositions of the transferase isoforms purified from Fractions Ib, II, III, IV and V are 


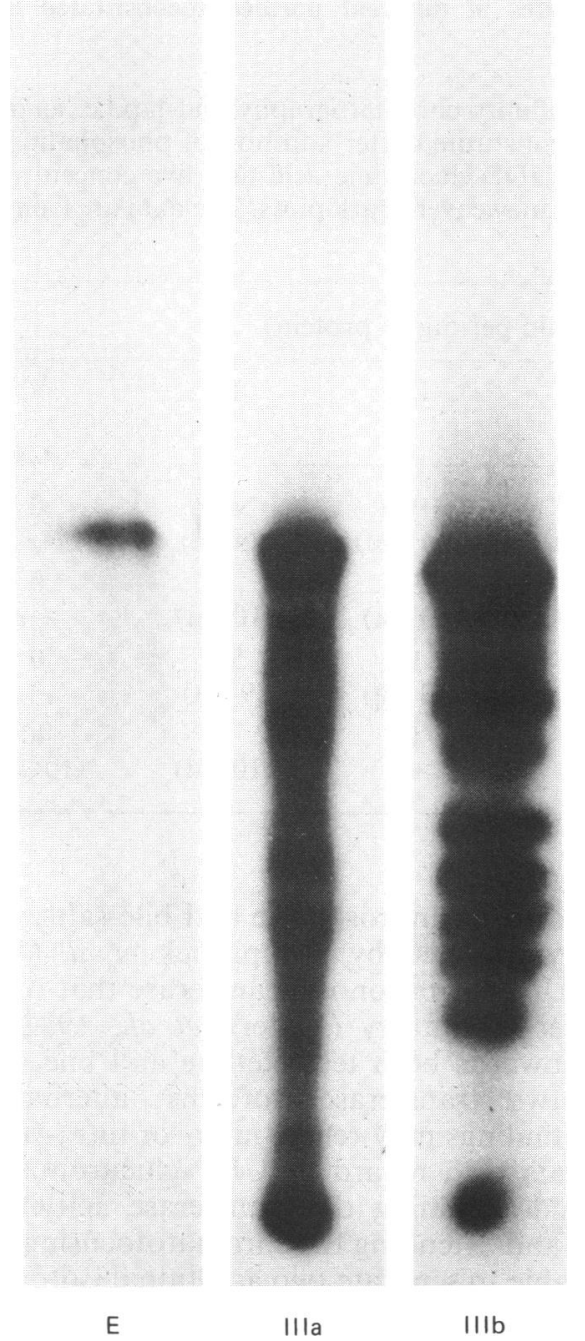

Fig. 5. Electrophoretic mapping of peptides produced by limited enzymic proteolysis of the two bands of UDP-glucuronosyltransferase Isoform III separated by $\mathrm{NaDodSO}_{4} /$ polyacrylamide-gel electrophoresis

Purified Isoform III was electrophoresed and the two bands were detected after Coomassie Blue staining as in Fig. 3(a); each of the two protein bands was removed by excision. The proteins were labelled with ${ }^{125} \mathrm{I}$ and digested with staphylococcal proteinase V-8; the resulting peptides were separated by gradient $\mathrm{NaDodSO}_{4} / 10-20 \%$-polyacrylamide-gel electrophoresis and identified by autoradiography. Undigested upper band of UDP-glucuronosyltransferase Isoform III (E), and the digestion products of the upper (IIIa) band and lower (IIIb) band of Isoform III are shown.

shown in Table 4. Comparison of the amino acid composition of the isoforms by the method of CornishBowden (1980) showed the following $S \Delta N$ values: Isoform Ib versus Isoforms II, III, IV and V, 139, 337, 246, and 263 respectively; Isoform II versus Isoforms III, IV and V, 241, 253 and 333 respectively; Isoform III versus Isoforms IV and V, 449 and 389 respectively; Isoform IV versus Isoform V, 385. According to Cornish-Bowden (1980), these results suggest an almost certain structural relatedness of Isoforms Ib and II, and possible relatedness of all other isoforms. The order of elution of the isoforms on chromatofocusing could not be predicted from the difference between their acidic and basic amino acid residues; this may be the consequence of differences in the content of charged sugars or asparagine and glutamine (which are not measured in the present method of analysis), or may reflect the possibility that all charged amino acids are not exposed in the non-denatured isoforms.

\section{Peptide maps}

Peptide maps produced by reverse-phase h.p.l.c. of tryptic digest of the purified isoforms revealed areas of uniqueness for Isoforms Ib, II, III, IV and V (Fig. 4), strongly suggesting differences in primary structure. Peptide maps of a given isoform from three different batches of purification were similar. Since the two bands of Isoform III could not be separated from each other except by $\mathrm{NaDodSO}_{4} /$ polyacrylamide-gel electrophoresis, these two proteins could not be separately subjected to h.p.l.c. peptide mapping. To compare their structures, the electrophoretically separated bands were radiolabelled and subjected to limited enzymic proteolysis within the gel, and the peptides produced were analysed by $\mathrm{NaDodSO}_{4} /$ polyacrylamide-gel electrophoresis; significant differences in the peptide pattern were observed (Fig. 5). No fragments were observed in control experiments in the absence of proteinase.

\section{Molecular size of non-denatured Isoforms I and III}

Apparent $M_{\mathrm{r}}$ values of these isoforms as determined by agarose gel-permeation chromatography were 310000 .

\section{Kinetic studies}

Apparent $K_{\mathrm{m}}$ and $V_{\max }$. values for several aglycone substrates were determined for purified UDP-glucuronosyltransferase isoforms (Table 5).

\section{DISCUSSION}

UDP-glucuronosyltransferases are intrinsic membrane proteins (Dutton, 1980); the enzyme activity requires membrane lipids (Jansen \& Arias, 1975). Thus the differential effects of ontogenic development, enzymeinducing agents, detergents and physical agents on enzyme activity towards various substrates may result from either multiplicity of the enzyme or changes in membrane lipid or cofactors. UDP-glucuronosyltransferase activities towards various substrates have been chromatographically separated, and corresponding isoforms have been purified in several laboratories (Bock et al., 1979; Burchell, 1978, 1981; Weatherill \& Burchell, 1980; Tukey \& Tephly, 1981; Falany \& Tephly, 1983; Falany et al., 1983; Roy Chowdhury et al., 1983). However, since different lipid or detergent contents may possibly result in differences in chromatographic mobility and function of an identical protein, true multiplicity of the transferases can be proved only by structural analysis of purified isoforms. Limited peptide mapping of two UDP-glucuronosyltransferases isolated from rabbit liver indicated structural differences between the two isoforms (Tukey \& Tephly, 1981); detailed structural analysis of rat liver UDP-glucuronosyltransferases has not been previously performed. In the present study, we have shown by h.p.l.c. mapping of tryptic peptides that rat liver UDP-glucuronosyltransferase Isoforms Ib, II, IV and $\mathrm{V}$ differ in primary protein structure, and the difference in structure between the two 
Table 5. Calculated $V_{\max }$ and $K_{\mathrm{m}}$ (in parentheses) for some aglycone substrates of different purified reconstituted isoforms of UDP-glucuronosyltransferase

UDP-glucuronosyltransferase isoforms were purified by chromatofocusing, affinity chromatography and h.p.l.c. as described in the Experimental section. UDP-glucuronosyltransferase activities were reconstituted after addition of phosphatidylcholine liposomes, and enzyme activities were determined at two concentrations of UDP-glucuronic acid and five concentrations of each of the aglycone substrates; $V_{\max }$ and apparent $K_{\mathrm{m}}$ were calculated from Lineweaver-Burk plots. The data are from a single representative experiment. Abbreviation: N.D., not determined.

\begin{tabular}{|c|c|c|c|c|c|c|}
\hline \multirow[b]{2}{*}{$\begin{array}{l}\text { Enzyme isoform... } \\
\text { Substrate }\end{array}$} & \multicolumn{6}{|c|}{$V_{\text {max. }}(\mathrm{nmol} / \mathrm{min}$ per $\mathrm{mg}$ of protein) } \\
\hline & $\mathrm{Ib}$ & Ic & II & III & IV & V \\
\hline 4-Nitrophenol & $\begin{array}{c}2980 \\
(1.8 \mathrm{mM})\end{array}$ & $\begin{array}{c}5500 \\
(0.5 \mathrm{~mm})\end{array}$ & $\begin{array}{c}1980 \\
(1.3 \mathrm{mM})\end{array}$ & $\begin{array}{c}1990 \\
(1.4 \mathrm{~mm})\end{array}$ & $\begin{array}{l}\text { N.D. } \\
\text { (N.D.) }\end{array}$ & $\underline{0}$ \\
\hline Testosterone & $\begin{array}{c}188 \\
(11 \mu \mathrm{M})\end{array}$ & $\underline{0}$ & $\begin{array}{c}330 \\
(9 \mu \mathrm{M})\end{array}$ & $\begin{array}{c}290 \\
(10 \mu \mathrm{M})\end{array}$ & $\begin{array}{c}30 \\
(10 \mu \mathrm{M})\end{array}$ & $\underline{0}$ \\
\hline Androsterone & $\underline{0}$ & $\underline{0}$ & $\underline{0}$ & $\begin{array}{c}90 \\
(10 \mu \mathrm{M})\end{array}$ & $\begin{array}{c}500 \\
(9 \mu \mathrm{M})\end{array}$ & $\underline{0}$ \\
\hline Bilirubin & $\frac{0}{-}$ & $\underline{0}$ & $\underline{0}$ & $\underline{0}$ & $\begin{array}{c}30 \\
(10 \mu \mathrm{M})\end{array}$ & $\begin{array}{c}40 \\
(10 \mu \mathrm{M})\end{array}$ \\
\hline
\end{tabular}

protein bands of Isoform III was shown by electrophoretic analysis of peptides produced by limited enzymic proteolysis. In addition, Isoforms Ic and VI were distinguished by their chromatographic mobility and substrate-specificity. Isoform Ic was available in too small a quantity for structural analysis, and Isoform VI was not obtained in pure state. Although Ia was a major subfraction that was derived from chromatofocusing fraction I, it had a much lower specific activity compared with subfractions Ib and Ic. Moreover, subfraction Ia was eluted from UDP-hexanolamine-Sepharose 4B column by $\mathrm{KCl}$ wash, rather than by UDP-glucuronic acid elution. For these reasons, the presence of a contaminating protein(s) in subfraction Ia was suspected, and its structural analysis was deferred.

Each purified isoform, except Isoform III, was homogeneous by $\mathrm{NaDodSO}_{4} /$ polyacrylamide-gel electrophoresis. Isoform III revealed two bands and could possibly represent a mixture of Isoforms II and IV or Isoforms II and V. However, this is unlikely for the following reasons. Isoforms II and V were inactive towards aniline, whereas enzyme specific activity in Isoform III was higher compared with Isoform IV. Had Isoform III been a mixture of Isoforms II and IV (or V), it might be expected to have a lower enzyme specific activity towards aniline, compared with Isoform IV. Moreover, tryptic peptides of Isoforms II, IV and V, that were eluted between 20 and $28 \mathrm{~min}$, were not present in the tryptic map of Isoform III. Results of target analysis suggest that UDP-glucuronosyltransferases may exist as oligomers (Peters et al., 1984); however, it is not clear whether the two bands of Isoform III are subunits of a single dimeric protein.

In previous studies involving the use of chromatofocusing of rat liver microsomes, we reported the separation of three fractions of transferase activity (Falany et al., 1983). Fractions A (elution pH 8.9) and B (elution $\mathrm{pH} \mathrm{8.5)}$ of that previous investigation correspond to Fractions I and II of the present study; Fraction $\mathrm{C}$ was resolved into Fractions III and IV in the present study. Fraction IV corresponds to the isoform with activity towards androsterone and bile salts, which was previously reported by Kirkpatrick et al. (1984). The form of UDP-glucuronosyltransferase that was purified in another laboratory (Matern et al., 1982) and had activity towards both testosterone and bile salts might contain two transferase isoforms; alternatively, the different findings may reflect inter- or intra-strain variation in rats with regard to UDP-glucuronosyltransferases. By determining the transferase activity towards bilirubin and extending the chromatofocusing to $\mathrm{pH} \mathrm{6.0,}$ we were able to separate two additional isoforms ( $V$ and VI). The present separation of six forms of UDP-glucuronosyltransferase activity was due to the excellent resolution provided by chromatofocusing and a decreased protein load per metre length of the column; the choice of solubilizing detergent also contributed. The remarkable degree of enrichment of the UDP-glucuronosyltransferase isoforms by chromatofocusing found in this strain of rats was not observed with other rat strains (Falany \& Tephly, 1983) and other species (e.g. human liver). The elution $\mathrm{pH}$ and protein-binding capacity of different lots of PBE-94 gel also vary considerably; however, with the same batch of chromatofocusing gel, these characteristics were reproducible.

UDP-glucuronosyltransferase Isoform $\mathrm{V}$ was active towards bilirubin alone; other isoforms had overlapping but distinct substrate-specificities. Each transferase isoform had activity towards natural metabolite substrates, except Isoform Ic, for which we lack a metabolite substrate. Investigation of glucuronidation of additional aglycone substrates may reveal additional isoforms of UDP-glucuronosyltransferase.

The work was partly supported by National Institutes of Health Grants AM 2019, AM 34357 and AM 17702. J.R.C. is recipient of National Institutes of Health Research Career Award AM 1016.

\section{REFERENCES}

Arias, I. M. (1961) Biochem. Biophys. Res. Commun. 6, 81-84 Axelrod, J., Inscoe, J. \& Tomkins, G. M. (1958) J. Biol. Chem. 232, 835-841 
Bock, K. W., Josting, D., Lillienblum, W. \& Pfeil, H. (1979) Eur. J. Biochem. 98, 19-26

Bradford, M. (1976) Anal. Biochem. 72, 248-253

Burchell, B. (1978) Biochem. J. 173, 749-757

Burchell, B. (1980) Methods Enzymol. 97, 188-192

Burchell, B. (1981) Rev. Biochem. Toxicol. 3, 1-32

Cornish-Bowden, A. (1980) Anal. Biochem. 105, 233-238

Dutton, G. J. (1980) Glucuronidation of Drugs and Other Compounds, pp. 23-28, CRC Press, Boca Raton, FL

Dutton, G. J. \& Burchell, B. (1977) Prog. Drug Metab. 2, $1-70$

Dutton, G. J., Leakey, J. E. A. \& Pollard, M. R. (1981) Methods Enzymol. 97, 383-391

Elder, J. H., Pickett, R. A., Hampton, J. \& Lerner, R. A. (1977) J. Biol. Chem. 252, 6510-6515

Falany, C. N. \& Tephly, T. R. (1983) Arch. Biochem. Biophys. 227, 248-258

Falany, C. N., Roy Chowdhury, J., Roy Chowdhury, N. \& Tephly, T. R. (1983) Drug Metab. Dispos. 11, 426-432

Glazer, A. N., DeLange, R. J. \& Sigman, D. S. (1969) Lab. Tech. Biochem. Mol. Biol. 4, 13-67

Gordon, A. H. (1969) Lab. Tech. Biochem. Mol. Biol. 1, 1-149

Jansen, P. L. M. \& Arias, I. M. (1975) Biochim. Biophys. Acta 391, 28-38

Jansen, P. L. M., Roy Chowdhury, J., Fischberg, E. B. \& Arias, I. M. (1977) J. Biol. Chem. 252, 2710-2716

Kirkpatrick, R. B., Falany, C. N. \& Tephly, T. R. (1984) J. Biol. Chem. 259, 6167-6180

Received 17 June 1985/11 September 1985; accepted 9 October 1985
Laemmli, U. K. (1970) Nature (London) 227, 680-685

Lillienblum, W., Walli, A. K. \& Bock, K. W. (1982) Biochem. Pharmacol. 31, 907-913

Lucier, G. W. \& McDaniel, O. S. (1977) J. Steroid Biochem. 8, 867-872

Mahoney, W. C. \& Hermodson, M. A. (1980) J. Biol. Chem. 255, 11199-11203

Matern, H., Matern, S. \& Gerok, W. (1982) J. Biol. Chem. 257, 7422-7429

Peters, W. H. M., Jansen, P. L. M. \& Nauta, H. (1984) J. Biol. Chem. 259, 11701-11705

Roy Chowdhury, J., Roy Chowdhury, N., Moscioni, A. D., Tukey, R., Tephly, T. \& Arias, I. M. (1983) Biochim. Biophys. Acta 761, 58-65

Roy Chowdhury, J., Novikoff, P. M., Roy Chowdhury, N. \& Novikoff, A. B. (1985) Proc. Natl. Acad. Sci. U.S.A. 82, 2990-2994

Sadler, E. J., Rearick, J. I., Paulson, J. C. \& Hill, R. L. (1979) J. Biol. Chem. 254, 4434-4443

Spiess, J., Villarreal, J. \& Vale, W. (1981) Biochemistry 20, 1981-1988

Tukey, R. H. \& Tephly, T. R. (1981) Arch. Biochem. Biophys. 209, 565-578

Weatherill, P. J. \& Burchell, B. (1980) Biochem. J. 189, 377-380

Weatherill, P. J., Kennedy, S. M. E. \& Burchell, B. (1980) Biochem. J. 191, 155-163

Wishart, G. J. (1978a) Biochem. J. 174, 485-489

Wishart, G. J. (1978b) Biochem. J. 174, 671-672 